\title{
PI3K-PKB/Akt Pathway
}

\section{Brian A. Hemmings and David F. Restuccia}

Friedrich Miescher Institute for Biomedical Research, Basel 4058, Switzerland

Correspondence: david.restuccia@fmi.ch

Identification of the phosphoinositide-3-kinase-protein kinase B/Akt (PI3K-PKB/Akt) pathway and activating receptor tyrosine kinases (RTKs) began in earnest in the early 1980s through vigorous attempts to characterize insulin receptor signaling (for review, see Alessi 2001; Brazil and Hemmings 2001). These humble beginnings led to the identification of the components and mechanism of insulin receptor signaling via insulin receptor substrate (IRS) proteins to PI3K and consequent PKB/Akt-mediated activation by 3 -phosphoinositide-dependent protein kinase 1 (PDK1). With the discovery of the potent contribution of $\mathrm{PI} 3 \mathrm{~K}$ and $\mathrm{PKB} / \mathrm{Akt}$ activation to tumorigenesis, intense research into the regulation of this pathway led to the discovery of the negative regulators, the protein phosphatase 2 (PP2A), phosphatase and tensin homolog (PTEN), and the $\mathrm{PH}$-domain leucine-rich-repeat-containing protein phosphatases (PHLPP1/2). More recently, the elusive PKB/
Akt hydrophobic motif kinases-i.e., the mammalian target of rapamycin (mTOR), when associated with the mTOR complex 2 (mTORC2), and the DNA-dependent protein kinase (DNA-PK) — were identified, as was the ability of Ras to affect the PI3K-PKB/Akt pathway via PI3K, completing our current model of the PI3K-PKB/Akt pathway.

The PI3K-PKB/Akt pathway is highly conserved, and its activation is tightly controlled via a multistep process (as shown in Fig. 1) Activated receptors directly stimulate class $1 \mathrm{~A}$ PI3Ks bound via their regulatory subunit or adapter molecules such as the insulin receptor substrate (IRS) proteins. This triggers activation of PI3K and conversion by its catalytic domain of phosphatidylinositol $(3,4)$-bisphosphate $\left(\mathrm{PIP}_{2}\right)$ lipids to phosphatidylinositol $(3,4,5)$-trisphosphate $\left(\mathrm{PIP}_{3}\right) . \mathrm{PKB} /$ Akt binds to $\mathrm{PIP}_{3}$ at the plasma membrane, allowing PDK1 to access and phosphorylate

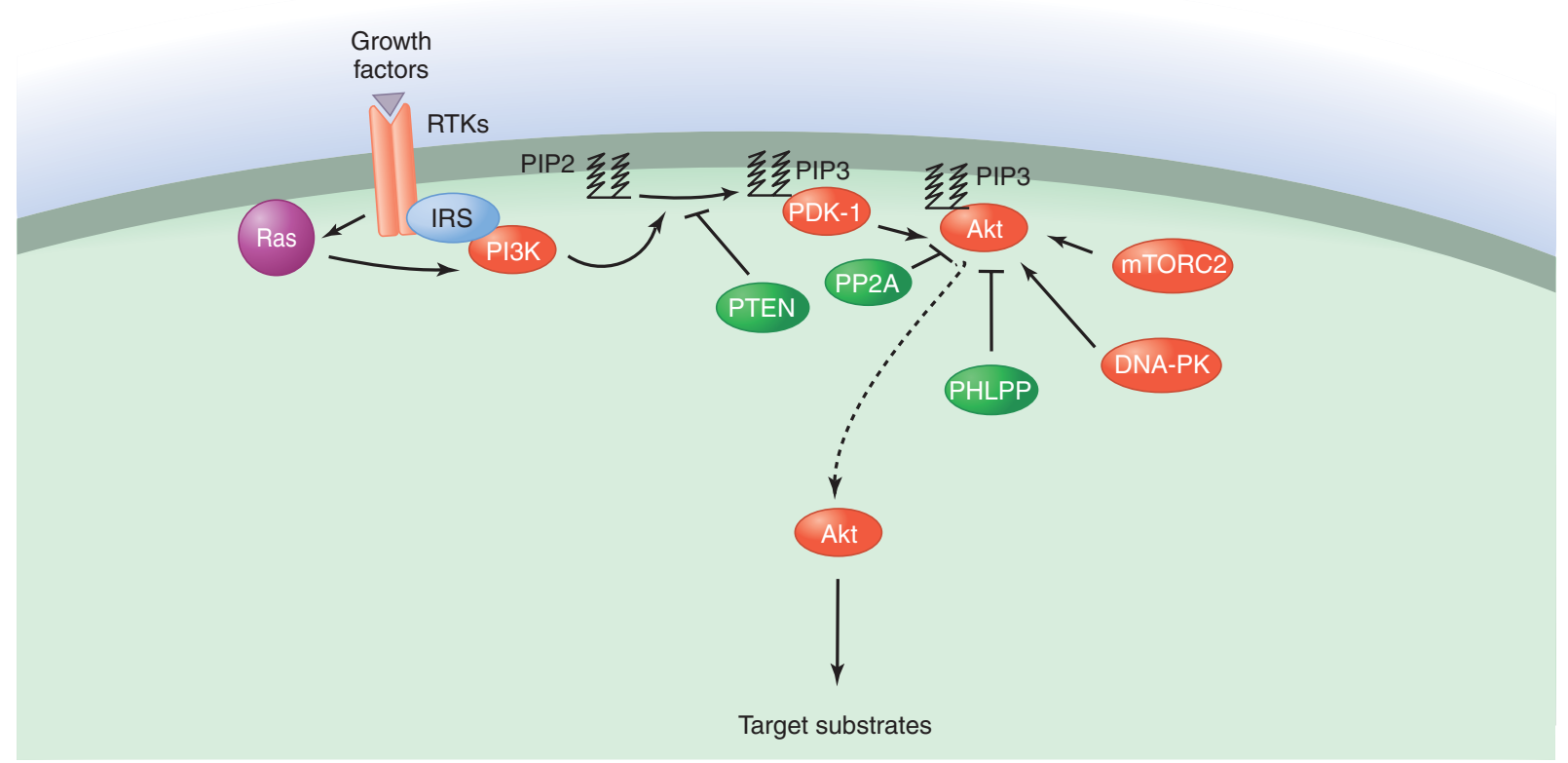

Figure 1. PKB/Akt activation downstream of RTKs via the P13K pathway.

Editors: Lewis Cantley, Tony Hunter, Richard Sever, and Jeremy Thorner

Additional Perspectives on Signal Transduction available at www.cshperspectives.org 


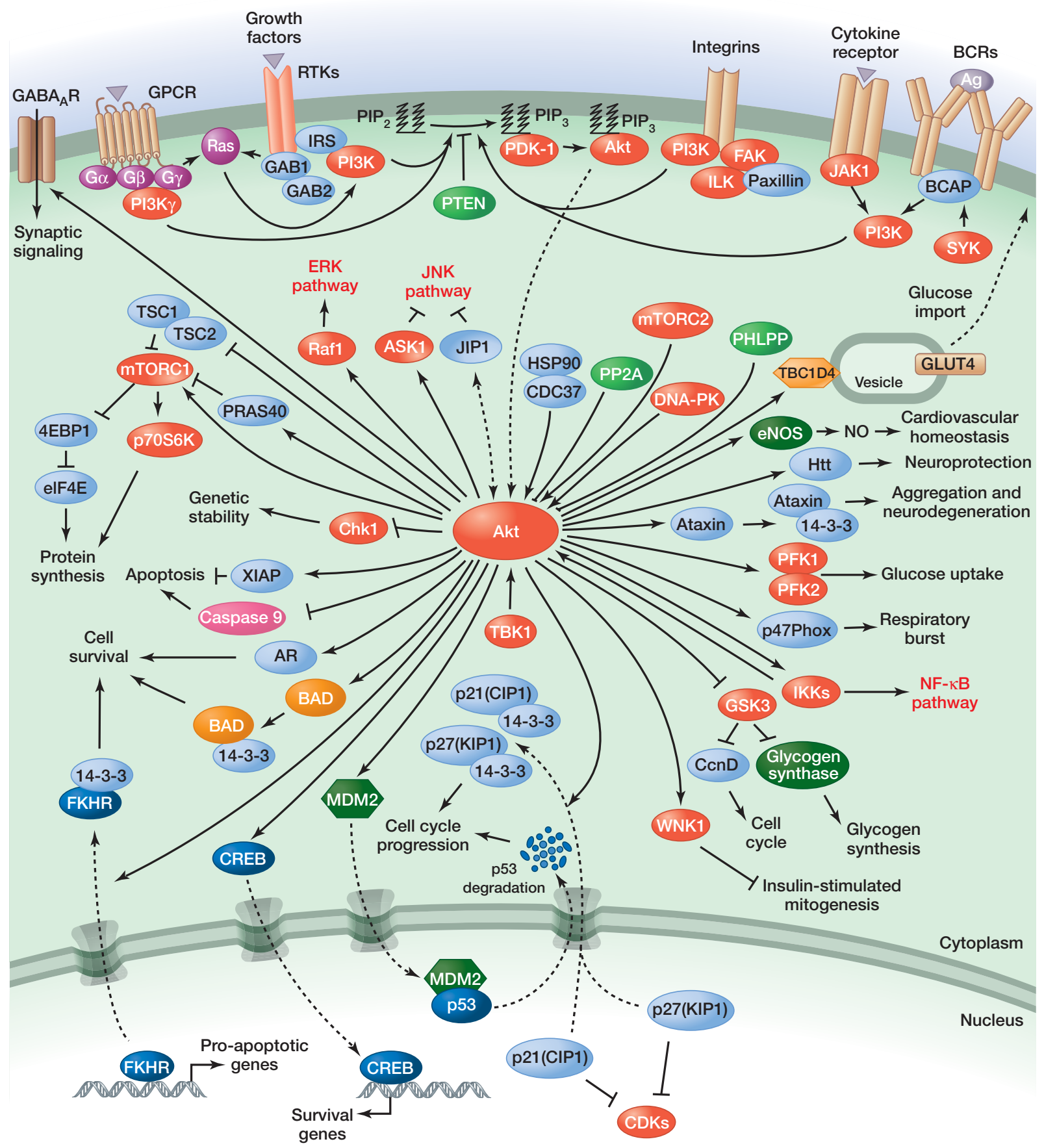

Figure 2. Signalling events activating PKB/Akt and cellular functions regulated by PKB/Akt.

T308 in the "activation loop," leading to partial PKB/Akt activation (Alessi et al. 1997). This PKB/Akt modification is sufficient to activate mTORC1 by directly phosphorylating and inactivating proline-rich Akt substrate of $40 \mathrm{kDa}$ (PRAS40) and tuberous sclerosis protein 2 (TSC2) (Vander Haar et al. 2007). mTORC1 substrates include the eukaryotic translation initiation factor $4 \mathrm{E}$ binding protein 1 (4EBP1), and ribosomal protein S6 kinase, $70 \mathrm{kDa}$, polypeptide 1 (S6K1), which, in turn, phosphorylates the ribosomal protein S6 (S6/RPS6), promoting protein synthesis and cellular proliferation.Figure 1.

Phosphorylation of Akt at $\$ 473$ in the carboxy-terminal hydrophobic motif, either by mTOR (Sarbassov et al. 2005) or by DNA-PK (Feng et al. 2004), stimulates full Akt activity. 
Full activation of Akt leads to additional substrate-specific phosphorylation events in both the cytoplasm and nucleus, including inhibitory phosphorylation of the pro-apoptotic FOXO proteins (Guertin et al. 2006). Fully active PKB/Akt mediates numerous cellular functions including angiogenesis, metabolism, growth, proliferation, survival, protein synthesis, transcription, and apoptosis (as shown in Fig. 2). Dephosphorylation of T308 by PP2A (Andjelković et al. 1996), and S473 by PHLPP1/2 (Brognard et al. 2007), and the conversion of $\mathrm{PIP}_{3}$ to $\mathrm{PIP}_{2}$ by PTEN (Stambolic et al. 1998) antagonize Akt signaling.Figure 2.

Figures adapted, with kind permission, from Cell Signaling Technology (http://www.cellsignal.com.)

\section{REFERENCES}

Alessi DR. 2001. Discovery of PDK1, one of the missing links in insulin signal transduction. Colworth Medal Lecture. Biochem Soc Trans 29: 1-14.

Alessi DR, James SR, Downes CP, Holmes AB, Gaffney PR, Reese CB, Cohen P. 1997. Characterization of a 3-phosphoinositide-dependent protein kinase which phosphorylates and activates protein kinase $B \alpha$. Curr Biol 7: 261-269.

Altomare DA, Testa JR. 2005. Perturbations of the AKT signaling pathway in human cancer. Oncogene 24: 7455-7464.

Andjelković M, Jakubowicz T, Cron P, Ming XF, Han JW, Hemmings BA. 1996. Activation and phosphorylation of a pleckstrin homology domain containing protein kinase (RAC-PK/PKB) promoted by serum and protein phosphatase inhibitors. Proc Natl Acad Sci 93: 5699-5704.

Bozulic L, Hemmings BA. 2009. PIKKing on PKB: Regulation of PKB activity by phosphorylation. Curr Opin Cell Biol 21: 256-261.

Brazil DP, Hemmings BA. 2001. Ten years of protein kinase B signalling: A hard Akt to follow. Trends Biochem Sci 26: 657-664.

Brognard J, Sierecki E, Gao T, Newton AC. 2007. PHLPP and a second isoform, PHLPP2, differentially attenuate the amplitude of Akt signaling by regulating distinct Akt isoforms. Mol Cell 25: 917-931.

Feng J, Park J, Cron P, Hess D, Hemmings BA. 2004. Identification of a $\mathrm{PKB} /$ Akt hydrophobic motif Ser-473 kinase as DNA-dependent protein kinase. J Biol Chem 279: 41189-41196.

Guertin DA, Stevens DM, Thoreen CC, Burds AA, Kalaany NY, Moffat J, Brown M, Fitzgerald KJ, Sabatini DM. 2006. Ablation in mice of the mTORC components raptor, rictor, or mLST8 reveals that mTORC2 is required for signaling to Akt-FOXO and $\mathrm{PKC} \alpha$, but not $\mathrm{S} 6 \mathrm{~K} 1$. Dev Cell 11: 859-871.

Manning BD, Cantley LC. 2007. AKT/PKB signaling: Navigating downstream. Cell 129: 1261-1274.

Sarbassov DD, Guertin DA, Ali SM, Sabatini DM. 2005. Phosphorylation and regulation of Akt/PKB by the rictor-mTOR complex. Science 307: $1098-1101$

Stambolic V, Suzuki A, de la Pompa JL, Brothers GM, Mirtsos C, Sasaki T, Ruland J, Penninger JM, Siderovski DP, Mak TW. 1998. Negative regulation of $\mathrm{PKB} /$ Akt-dependent cell survival by the tumor suppressor PTEN. Cell 95: 29-39.

Vander Haar E, Lee SI, Bandhakavi S, Griffin TJ, Kim DH. 2007. Insulin signalling to mTOR mediated by the Akt/PKB substrate PRAS40. Nat Cell Biol 9: 316-323. 


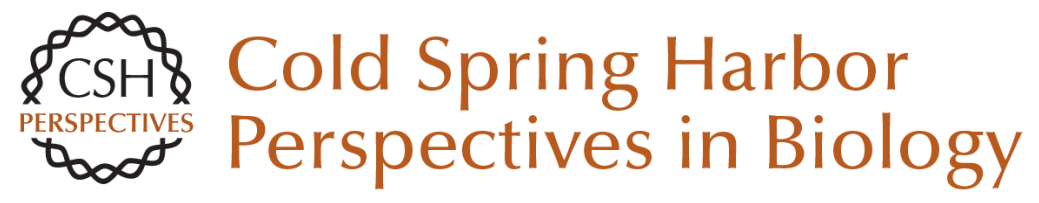

\section{PI3K-PKB/Akt Pathway}

Brian A. Hemmings and David F. Restuccia

Cold Spring Harb Perspect Biol 2012; doi: 10.1101/cshperspect.a011189

Subject Collection Signal Transduction

Cell Signaling and Stress Responses Gökhan S. Hotamisligil and Roger J. Davis

Protein Regulation in Signal Transduction Michael J. Lee and Michael B. Yaffe

Synaptic Signaling in Learning and Memory Mary B. Kennedy

Vertebrate Reproduction Sally Kornbluth and Rafael Fissore

Signaling in Lymphocyte Activation Doreen Cantrell

Signaling in Muscle Contraction Ivana Y. Kuo and Barbara E. Ehrlich

Toll-Like Receptor Signaling Kian-Huat Lim and Louis M. Staudt

Signaling Pathways that Regulate Cell Division Nicholas Rhind and Paul Russell
Second Messengers

Alexandra C. Newton, Martin D. Bootman and John D. Scott

Signals and Receptors Carl-Henrik Heldin, Benson Lu, Ron Evans, et al.

Cell Death Signaling Douglas $R$. Green and Fabien Llambi

Signaling Networks that Regulate Cell Migration Peter Devreotes and Alan Rick Horwitz

Signaling Networks: Information Flow, Computation, and Decision Making Evren U. Azeloglu and Ravi lyengar

Signal Transduction: From the Atomic Age to the Post-Genomic Era Jeremy Thorner, Tony Hunter, Lewis C. Cantley, et al.

Signaling by the TGF $\beta$ Superfamily Jeffrey L. Wrana

Subversion of Cell Signaling by Pathogens Neal M. Alto and Kim Orth

For additional articles in this collection, see http://cshperspectives.cshlp.org/cgi/collection/

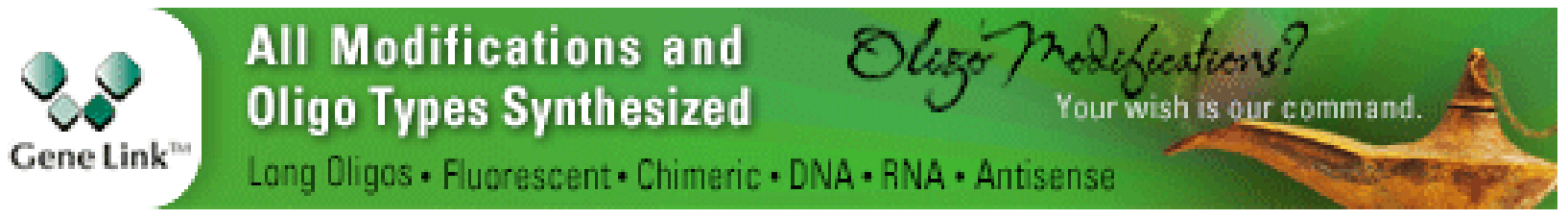

Copyright (C 2012 Cold Spring Harbor Laboratory Press; all rights reserved 